\title{
The association of total body composition with trunk strength, pain and disability in patients with lumbar osteoarthritis
}

\author{
Asociación de la composición corporal total con la fuerza del tronco, el dolor y la \\ discapacidad en pacientes con espondiloartrosis lumbar
}

\section{Tania I. Nava-Bringas ${ }^{1 *}$, Laura López-Domínguez1, Salvador I. Macías-Hernández ${ }^{1}$, Rolando Espinosa-Morales², Daniel D. Chávez-Arias ${ }^{3}$ and Roberto Coronado-Zarco ${ }^{4}$}

${ }^{1}$ Orthopedic Rehabilitation Division; ${ }^{2}$ Department of Rheumatology. Collaborating Center of the Pan-American Health Organization/World Health Organization for Medical Research and Rehabilitation; ${ }^{3}$ Medical Directorate; ${ }^{4}$ Sub-directorate of Rehabilitation Medicine. Instituto Nacional de Rehabilitación Luis Guillermo Ibarra Ibarra, Mexico City, Mexico

\begin{abstract}
Background: Variations in body composition among patients with lumbar osteoarthritis may influence pain and disability and muscle strength. Objective: To analyze the relationship between body composition with pain, disability and muscle strength, in patients with lumbar osteoarthritis. Methods: Pilot study in patients older than 50 years of age, with chronic low back pain and lumbar osteoarthritis, who agreed to participate through informed consent. We excluded patients with diabetes mellitus, depression, anxiety, inflammatory arthropathies, vertebral fractures, idiopathic scoliosis, spinal surgery, heart disease or hypertension, radiculopathy or neurogenic claudication. Data on evolution time, body composition (total body fat and musscle mass), trunk strength, pain (numerical rating scale), and disability (Roland Morris questionnaire) were collected. Mann-Whitney U-test and Spearman correlations were performed. Results: 27 patients (18 women and 9 men) aged $58.59 \pm 6.98$ years. Negative correlations between muscle mass with pain (rho: $-0.63, p=0.001$ ) and strength (flexors rho: $-0.42, p=0.02$; extensors rho: $-0.50, p=0.007$ ) were found, without correlation with disability. No correlations of fat mass with pain or disability were found. Conclusion: Decreased of muscle mass were associated with higher pain scores without influencing-the disability in patients with lumbar osteoarthritis.
\end{abstract}

KEY WORDS: Body composition. Strength. Pain. Disability. Lumbar osteoarthritis.

\section{Resumen}

Introducción: Las alteraciones en la composición corporal total podrían influir sobre la fuerza, el dolor y la discapacidad en pacientes con espondiloartrosis lumbar. Objetivo: Analizar la asociación de la composición corporal total con la fuerza muscular del tronco, el dolor y la discapacidad en pacientes con espondiloartrosis lumbar. Método: Estudio piloto en mayores de 50 años con dolor crónico de espalda baja y espondiloartrosis lumbar. Se excluyeron pacientes con diabetes mellitus, depresión, ansiedad, artropatías inflamatorias, fracturas vertebrales, escoliosis, cirugías de columna, cardiopatías, hipertensión arterial, radiculopatía o claudicación neurogénica. Se recolectaron datos sobre tiempo de evolución, composición corporal (masasa grasa y muscular total), fuerza del tronco (isocinesia), dolor (escala numérica verbal) y discapacidad (Roland Morris). Análisis estadístico con $U$ de Mann-Whitney y correlaciones de Spearman. Resultados: 27 pacientes (18 mujeres y 9 hombres) 5 con

\author{
Correspondence: \\ *Tania I. Nava-Bringas \\ Av. México-Xochimilco 289, \\ Col. Arenal de Guadalupe, Del. Tlalpan \\ C.P. 14389, Mexico City, Mexico \\ E-mail: tanianava@gmail.com
}

Date of reception: 29-11-2017

Date of acceptance: 26-05-2018

DOI: $10.24875 / C I R U E . M 18000058$
Cir Cir. 2018;86:339-342

Contents available at PubMed www.cirugiaycirujanos.com 
edad de $58.59 \pm 6.98$ años. La masa muscular total se asoció con el dolor (rho: $-0.63, p=0.001$ ) y con la fuerza del tronco (flexores rho: $-0.42, p=0.02$; extensores rho: $-0.50, p=0.007$ ), sin correlación con la discapacidad. No se encontró correlación de la masa grasa con ninguna de las variables. Conclusión: La disminución de la masa muscular se asocia cön el dolor, pero no con la discapacidad, en pacientes con espondiloartrosis lumbar.

PALABRAS CLAVE: Composición corporal. Fuerza. Dolor. Discapacidad. Espondiloartrosis lumbar.

\section{Introduction}

Spinal osteoarthritis refers to degenerative changes that occur in the vertebral column as a consequence of osteoarthritis. It is one of the main causes of chronic low back pain and disability in individuals older than 50 years 1 .

Spinal osteoarthritis primarily affects the facet joints (zygapophysial joints), although often it is found associated with intervertebral disc degeneration and is one of the main risk factors for subsequent facet joint degeneration ${ }^{2,3}$.

Up to $67 \%$ of people older than 50 years have lumbar spine osteoarthritis on imaging exams, but not everyone experiences pain or functional limitation, and even clinical manifestations vary from one subject to another without a direct relationship with the degree of osteoarthritis present ${ }^{4,5}$.

A possible explanation for these clinical variations is the presence of alterations in total body composition (TBC) of individuals affected by lumbar osteoarthritis, primarily those related to changes in adipose and muscle tissues.

There are studies that have shown an association of aging-related morbidity and mortality with TBC alterations ${ }^{6,7}$. Similarly, some studies in specific pathologies, such as knee osteoarthritis, have suggested that TBC alterations can act as risk factors that are independent of mechanical loading of joints, which modify the pain experienced, functionality and clinical course of the disease ${ }^{8,9}$.

Recently, a study was published that found an association between the degree of fat infiltration in paraspinal muscles and the degree of lumbar osteoarthritis, but clinical variables such as pain or the degree of disability experienced by patients with lumbar osteoarthritis were not taken into account in this study ${ }^{10}$.

Currently, there is no information available on the association between TBC alterations and pain and functional disability in patients with chronic pain secondary to lumbar osteoarthritis and, therefore, the purpose of the present study was to carry out a preliminary analysis of these issues.

\section{Method}

A pilot study was conducted, with non-probabilistic convenience sampling in subjects older than 50 years, of either gender, with radiographic diagnosis of lumbar osteoarthritis and presence of chronic lumbar pain (more than 3 months' evolution), who were under the care of the spine rehabilitation department of the Luis Guillermo Ibarra Ibarra National Rehabilitation Institute.

The protocol of this research was previously approved and registered by the Institutional Research Committee, with registration number 69/15. All patients participated voluntarily, with the signature of an informed consent document being obtained for purpose.

For radiographic diagnosis, the presence of at least two functional lumbar spine segments with findings suggestive of facet osteoarthritis (joint space reduction, sclerosis, osteophyte formation) was considered including data consistent with disc degeneration (intersomatic space reduction and vertebral platform sclerosis).

Patients with comorbidities such as diabetes mellitus, depression, anxiety, inflammatory rheumatic conditions, history of vertebral fractures, idiopathic scoliosis, previous spine surgeries, ischemic hêrt disease or uncontrolled high blood pressure, as \$well as those with clinical data consistent with acuteradicular involvement or lumbar stenosis (neurogenic claudication), were excluded.

Data on age and time of evolution were collected. Pain was assessed using the verbal numerical scale, asking the patient to choose the number that best represented the pain experienced within the previous 7 days, with 0 being considered as no pain and 10 as the worst possible pain. To assess disability, the Roland-Morris questionnaire, which is a 24 -item, applicable instrument that reflects the limitations in daily life activities associates with chronic lower back pain, was applied. Total score can range from 09 (no disability) to 24 (maximum disability).

To assess the strength of the trunk muscles, concentric isokinesia tests were performed on a CON-TREX 
dynamometer using the following protocol: after submaximal aerobic warming consisting of 5-minute free walk, the subject was placed in up right standing position on the platform of the dynamometer, verifying the correct sagittal and coronal alignment with respect to the rotational axis of the trunk (at the L5 level); fasteners were placed above and below the patella, on the pelvic and scapular waists, and automatic calibration of the equipment was performed; total range of movement of $20^{\circ}$ of flexion-extension of the trunk was established for the performance of the test, and two tests were performed at $40 \%$ s angular velocity, each one with three repetitions at the most. At the end of the test, data on the peak torque in Newtons per meter were extracted in order to estimate the strength of the flexor and extensor muscle groups.

Bioelectrical impedance was used to assess TBC in an Imbody $720^{\circledR}$ equipment, using the following protocol: after having metal objects removed from the body, the patient was placed without shoes on the equipment, holding the sensors with both hands, with a 4-minute reading being taken, by means of which the values of the body mass index (BMI), total fat mass in kilograms, body fat percentage and skeletal muscle mass in kilograms were extracted for analysis. The equipment determines, according to the BMI, the normal value establishes for each subject over total fat mass and skeletal muscle mass, which yields the results to compare whether the individual is within normal or altered parameters.

Data analysis was performed with the SPSS statistical package, version 21. Descriptive statistics were used to summarize the data; nonparametric tests (Mann Whitney U-test) were chosen for data comparison and Spearman correlations for association of variables.

\section{Results}

Twenty-seven subjects ( 18 women and 9 men) with an average age of $58.59 \pm 6.98$ years were included. Pain symptoms evolution time was $1.72 \pm 1.59$ years. No significant differences were found in age and evolution time averages between genders.

Pain intensity measured with the numerical scale was $6.56 \pm 1.73$ points on average, and disability assessed with the Roland Morris scale had an average of $9.7 \pm 3.59$ points for the group, with no gender differences $(p \geq 0.05)$. The results for the strength of the trunk muscles (isokinesia) and the percentages of muscle and adipose tissue (TBC by impedanciometry) are shown in tables 1 and 2 , respectively.
Table 1. Muscle strength (torque spikes in Newtons) of the trunk flexor and extensor muscles

\begin{tabular}{|c|c|c|c|c|}
\hline & Gender & \multicolumn{2}{|c|}{ Mean } & $9 p$ \\
\hline \multirow[t]{2}{*}{ Trunk flexor muscles } & Female & \multicolumn{2}{|c|}{$115.0 \pm 32.8 \mathrm{~N}$} & $\overline{0} 23$ \\
\hline & Male & \multicolumn{2}{|c|}{$98.95 \pm 30.42 \mathrm{~N}$} & $\stackrel{\frac{1}{u}}{2}$ \\
\hline \multirow[t]{2}{*}{ Trunk extensor muscles } & Female & \multicolumn{2}{|c|}{$139.54 \pm 37.57 \mathrm{~N}$} & (9.46 \\
\hline & Male & \multicolumn{2}{|c|}{$126.65 \pm 52.27 \mathrm{~N}$} & $\frac{\check{L}}{d}$ \\
\hline \multicolumn{4}{|c|}{ Table 2. Overall body composition analysis results } & 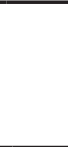 \\
\hline & Gender* & Mean & SD & $\frac{c}{+p}$ \\
\hline \multirow[t]{2}{*}{ Body mass index } & Female & 27.53 & 4.0 & 8.64 \\
\hline & Male & 31.0 & 4.98 & $\frac{.}{\sqrt{n}}$ \\
\hline \multirow[t]{2}{*}{ Skeletal muscle mass (kg) } & Female & 25.27 & 4.97 & 0.36 \\
\hline & Male & 23.52 & 3.84 & 르 \\
\hline \multirow[t]{2}{*}{ Body fat mass (kg) } & Female & 29.04 & 8.01 & 8.88 \\
\hline & Male & 29.03 & 10.2 & $\sum_{3}^{5}$ \\
\hline \multirow[t]{2}{*}{ Body fat percentage } & Female & 38.13 & 6.72 & 0.41 \\
\hline & Male & 40.53 & 7.66 & $\frac{0}{0}$ \\
\hline \multicolumn{4}{|c|}{$\begin{array}{l}{ }^{*} 18 \text { females and } 9 \text { males. } \\
{ }^{+} \text {Mann-Whitney U-test for mean comparisons between genders. } \\
\text { SD: standard deviation. }\end{array}$} & 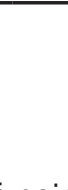 \\
\hline
\end{tabular}

In the correlation analysis, the association of pain scores with flexor muscle strength (rho: $-0,42$, $p=0.02$ ), extensor muscle strength (rho: -0.50 , $p=0.007$ ), muscle mass in kilograms (rho: -0.63 , $p=0.001$ ), fat mass in kilograms (rho: $-239, p=0.230$ ), total body fat percentage (rho: $0.086, p=0.67$ ), BMl (rho: $0.027, p=0.89$ ) and age (rho: $0.085, p=0.674$ ) was sought.

The association of the scores obtained with the Roland-Morris functionality questionnaire with flexor muscle strength (rho: $-0.115, p=0.567$ ), exte îsor muscle strength (rho: $-0.245, p=0.218$ ), muscle mass in kilograms (rho: $-0.031, p=0.877$ ), fat mass in kilograms (rho: $0.022, p=0.915$ ), total body fat percentage (rho: $-030, p=0.883$ ), BMI (rho: $-0.112, \frac{5}{0}=$ 0.577 ) and age (rho: $0.238, p=0.232$ ) was also sought.

\section{Discussion}

The information obtained in this pilot study confirms the importance of muscle tissue in patients with chronic pain and lumbar osteoarthritis. Previous studies using magnetic resonance imaging in subjects with chronic 
low back pain have associated muscle atrophy with the presence of chronic pain ${ }^{7,11}$.

Regarding adipose tissue and its implications in osteoarthritis, a tendency towards an increase has been observed in publications that refer the influence of adipose tissue on osteoarthritis natural evolution, with adipose tissue even being a risk factor that is independent of mechanical loading on joints, and data being mainly on knee and hand osteoarthritis; currently, there is little information available on the vertebral column $n^{8,9,12}$.

Only Urquhart et al. ${ }^{13}$ have conducted a TBC study with bioelectrical impedance analysis, in 135 subjects recruited from obesity clinics (aged between 25 and 62 years). In their study, questionnaires on lower back pain and disability in the previous 6 months were applied, and compared the study subjects with healthy volunteers, with an association of pain and disability with the increase in adipose tissue being found; however, no imaging studies of the spine were performed and no specific diagnosis was established.

In contrast to the above, in the present study, we did not demonstrate an association of adipose tissue percentage and total fat mass with the collected clinical variables (pain and disability), despite the fact that the vast majority of subjects in the study had higher-thanexpected values.

These findings should be taken with reservations. Our main limitation is the reduced sample of patients and an evolution time of less than 2 years, which may not represent all phases of lumbar spine osteoarthritis natural evolution. For this reason, we consider it relevant to broaden the number of individuals and consider the implications of adipose tissue that have been reported in other studies at osteoarthritis advanced stages.

\section{Conclusion}

Muscle mass decrease is associated with pain, but not with disability, in patients with lumbar osteoarthritis. No association was found between adipose tissue alterations and pain or disability in patients with lumbar osteoarthritis.

\section{Conflicts of interests}

The authors declare that they have no conflicts of interest relevant to the performance of this work.

\section{References}

1. Hunter DJ, Felson DT. Osteoarthritis. BMJ. 2006;332:639-42.

2. Gellhorn AC, Katz JN, Suri P. Osteoarthritis of the spine: the facet joints. Nat Rev Rheumatol. 2013;9:216-24.

3. Suri P, Miyakoshi A, Hunter DJ, Jarvik JG, Rainville J, Guermazi A et al Does lumbar spinal degeneration begin with the anterior structures? A study of the observed epidemiology in a community-based population. BMC Musculoskelet Disord. 2011;12:202.

4. Goode AP, Carey T, Jordan JM. Low back pain and lumbar spine osteoarthritis: how are they related? Curr Rheumatol Rep. 2013;15:305.

5. Hochberg MC, Altman RD, Brandt K, Clark B, Dieppe P, Griffin M, et al. Guidelines for the medical management of osteoarthritis. Arthritis Rheum. 1995;38:1541-6.

6. Francis P, Lyons M, Piasecki M, Mc Phee J, Hind K, Jakeman P. Measurement of muscle health in aging. Biogerontology. 2017;18:901-11

7. Kalichman L, Carmeli E, Been E. The association between imaging parameters of the paraspinal muscles, spinal degeneration, and low-back pain. Biomed Res Int. 2017;2017:2562957.

8. Zhuo Q, Yang W, Chen J, Wang Y. Metabolic syndrome meets osteoarthritis. Nat Rev Rheumatol. 2012;8:729-37.

9. Van der Esch M, Knoop J, van der Leeden M, Roorda LD, Lems WF, $\mathrm{Knol} \mathrm{DL}$, et al. Clinical phenotypes in patients with knee osteoarthritis: a study in the Amsterdam osteoarthritis cohort. Osteoarthr Cartil. 2015;23:544-9.

10. Yu B, Jiang K, Li X, Zhang J, Liu Z. Correlation of the features of the lumbar multifidus muscle with facet joint osteoarthritis. Orthopedics. 2017;40:e793-e800.

11. Danneels LA, Vanderstraeten GG, Cambier DC, Witvrouw EE, De Cuyper HJ. CT imaging of trunk muscles in chronic low back pain patients and healthy control subjects. Eur Spine J. 2000;9:266-72.

12. Zhang $P$, Zhong ZH, Yu HT, Liu B. Significance of increased leptin expression in osteoarthritis patients. PLoS One. 2015;10:e0123224.

13. Urquhart DM, Berry $P$, Wluka AE, Strauss BJ, Wang $Y$, Proietto Jet al. Increased fat mass is associated with high levels of low back painuntensity and disability. Spine (Phila Pa 1976). 2011;36:1320-5. 